\title{
Association of Serum Ferritin with Gestational Diabetes Mellitus
}

Mahmood $\mathrm{S}^{1^{*}}$, Fatema $\mathrm{K}^{2}$, Yousuf $\mathrm{S}^{3}$

\author{
${ }^{1}$ Dr. Sharmeen Mahmood, Associate Professor, Department of Obstetrics \& Gynaecology, Bangabandhu Sheikh Mujib Medical \\ University, Bangladesh \\ ${ }^{2}$ Dr. Kaniz Fatema, Associate Professor, Department of Obstetrics \& Gynaecology, Bangabandhu Sheikh Mujib Medical University, \\ Bangladesh \\ ${ }^{3}$ Dr. Shereen Yousuf, Medical Officer, Department of Obstetrics \& Gynaecology, Bangabandhu Sheikh Mujib Medical University, \\ Bangladesh
}

DOI: $10.36347 /$ sjams.2021.v09i02.001

| Received: 18.01.2021 | Accepted: 02.02.2021 | Published: 05.02.2021

*Corresponding author: Dr. Sharmeen Mahmood

Abstract

Original Research Article

Background: The aim of the present study was to evaluate the association of serum ferritin with GDM ( $\mathrm{n}=60)$ and without GDM $(n=60)$. The age and body mass index of the participants along with their gestational age, gravidity and parity were harmonized. The serum ferritin levels and blood glucose were investigated. The results revealed that pregnant women with GDM had significantly higher level of serum ferritin than their healthy counterparts. Methods: This cross sectional analytical study was done in Department of Obstetrics \&Gynaecology, Bangabandhu Sheikh Mujib Medical University (BSMMU), and Dhaka, Bangladesh during April 2019to march 2020.120 pregnant womenbetween 18-35 years of age attending antenatal clinic in their 24-34 weeks ofpregnancy were included in this study. Among them 60 diagnosed case of GDM wereconsider as group A and rest 60 (without GDM) were consider as group B. Serumferritin concentration was measured in all of these patient. Results: The mean serum ferritin level was $121.1+17.7 \mathrm{ng} / \mathrm{ml}$ and $86.4 \pm 19.9 \mathrm{ng} / \mathrm{ml}$ ingroup $\mathrm{A}$ and group B respectively. The difference was statistically significant $(\mathrm{p}<0.05)$ between two groups. More than half $(65.0 \%)$ patients had serum ferritinlevel $>120 \mathrm{ng} / \mathrm{ml} \mathrm{in}$ group A and $12(20.0 \%)$ in group B. Serum ferritin level $>120 \mathrm{ng} / \mathrm{ml}$ had 3.1 (95.0\% C.L. 1.6 to 7.60) times significantly $(\mathrm{p}<0.05)$ increase to developed gestational diabetes mellitus.Conclusion: The serum ferritin was markedly higher in women with GDM than without GDM. Therefore, high serum ferritin can be regarded as a significant risk factor for the development of GDM.

Keywords: Gestational diabetes mellitus, Pregnancy, Ferritin.

Copyright $\odot 2021$ The Author(s): This is an open-access article distributed under the terms of the Creative Commons Attribution 4.0 International License (CC BY-NC 4.0) which permits unrestricted use, distribution, and reproduction in any medium for non-commercial use provided the original author and source are credited.

\section{INTRODUCTION}

Among all obstetric complications, gestational diabetes mellitus (GDM) is a rising prevalence of a disorder characterized by variable severity of glucose intolerance with onset or first recognition in pregnancy, has been reported over the years, reaching $10-15 \%$ in the world [1] GDM is diagnosed when FBS is 5.1$6.9 \mathrm{mmoUL}$ or 2 hours plasma glucose is $8.5-11.0$ $\mathrm{mmol} / \mathrm{L}$ following a $75 \mathrm{~g}$ oral glucose load [1].

The prevalence of GDM varies among different races and ethnic groups [2]. In Bangladesh, the prevalence of GDM is $9.7 \%$ [3]. Certain groups of women are at increased risk of developing GDM. The risk factors are: age $>35$ years, $\mathrm{BMI}>30 \mathrm{~kg} / \mathrm{m} 2$, prior history of GDM, previous macrosomic baby (weight $>4.5 \mathrm{~kg}$ ), prior history of unexplained still birth, family history of diabetes and PCOS [2]. Women with GDM are unable to increase insulin production to compensate for the increased insulin resistance, resulting in $\beta$-cells deterioration and hyperglycaemia [4]. Serum ferritin concentration provides an indirect estimate of body iron stores be it is highly correlated with bone marrow iron. Ferritin is also a positive acute-phase reactant and increases in the presence of various acute or chronic disease conditions $[5,6]$.

Iron overload and the oxidative stress contribute to the pathogenesis and increase risk of type 2 diabetes. If iron overload, the accumulation interferes with the extraction, synthesis and secretion of insulin [7]. High level of ferritin was a risk factor for the development of gestational diabetes mellitus (GDM) in pregnant women [8].

Elevated serum ferritin concentration, which is associated with insulin resistance and diabetes in the 
general population, has also been recently described in GDM. In some studies, high iron level has beenshown to be a harmful factor for the body via oxidative stress and free radicals [9]. GDM is associated with an increased serum $\mathrm{C}$-reactive protein level; some authors suggest that GDM might be part of an inflammatory process [6, 10]. It has been previously reported that iron overload promotes inflammatory processes by inducing free radical formation through an oxidative mechanism [11]. GDM is a common pregnancy complication and is associated with increased maternal and neonatal morbidity. Identifying and treating women with or at risk for GDM is important to improve the outcomes. The objective of this study was to compare serum ferritin between GDM and without GDM patients and to determine the association of serum ferritin with GDM.

\section{Methodology}

This cross sectional analytical study was conducted in BSMMU, during April 2019 to March 2020. A total of 120 pregnant women of which 60 with GDM were one (Group A) and rest 60 without GDM were another group (Group B) were selected by nonrandom purposive sampling technique. The participants with GDM were used as experimental group while the healthy pregnant women without GDM within 18 to 35 years were selected as control group. Pregnant woman with history of diabetes mellitus, severe anaemia, haemoglobinopathies, acute or chronic infection, renal diseases, liver diseases, thyroid disorder were excluded from the study. Demographical variable were age of the pregnant women, educational status, occupational status, socio-economic status, exposure variable was Serum ferritin and outcome variable was GDM.
Venous blood $(5 \mathrm{ml})$ was taken from the ante cubital vein. Serum ferritin concentration was measured by Chemiluminescence Microparticles Immunoassay method (CMIA) in Abbott Architect system (ci4100). When there was delay the samples was stored $2-8^{\circ}$ Celsius for 7 days and if more delay, the samples was stored at $-20^{\circ}$ Celsius till further analysis. Normal level of serum ferritin in female: $22-120 \mathrm{ng} / \mathrm{mL}$.

Statistical analyses of the results were obtained by using window based computer software devised with Statistical Packages for Social Sciences (SPSS-22). Comparison of means made by using Student t-test and categorical data was analyze by Chi-square Test, Odds Ratio (OR) with $95 \%$ confidence interval and $\mathrm{p}$ value < 0.05 was considered significant.

\section{RESULTS}

The mean age was $29.5 \pm 4$ years in Group A and 28.1 \pm 4.4 years in Group B. The difference was statistically not significant $(p>0.05)$ between two groups. According to parity, it was observed that almost two third $(70.0 \%)$ patients were multipara in Group A and $39(65.0 \%)$ in GroupB. The difference was statistically not significant $(p>0.05)$ between two groups. The mean duration of gestation was $29.3 \pm 3.6$ weeks in Group A and 27.6 \pm 3.5 weeks in Group B. The difference was statistically not significant $(p>0.05)$ between two groups. The mean serum ferritin level was $121.1 \pm 17.7 \mathrm{ng} / \mathrm{ml}$ in Group A and 86.4 $\pm 19.9 \mathrm{ng} / \mathrm{ml}$ in Group B. The difference was statistically significant $(p<0.05)$ between two groups. Regarding association between elevated serum ferritin and GDM, it was observed that more than half $(65.0 \%)$ patients had serum ferritin level $>120 \mathrm{ng} / \mathrm{ml}$ in Group A and $12(20.0 \%)$ in Group B. Serum ferritin was significantly $(\mathrm{p}<0.05)$ increased $(3.1$ times $)$ to developed GDM.

Table-I: Distribution of the study patients by age ( $\mathrm{n}=120)$

\begin{tabular}{|l|l|l|l|l|l|}
\hline \multirow{2}{*}{ Age group (years) } & \multicolumn{2}{|l|}{ Group A } & \multicolumn{2}{l|}{ Group B } & \multirow{2}{*}{ P-Value } \\
\cline { 2 - 5 } & $\mathbf{n = 6 0}$ & $\mathbf{\%}$ & $\mathbf{n}=\mathbf{6 0}$ & $\mathbf{\%}$ & \\
\hline$<20$ & 0 & 0.0 & 3 & 5.0 & \\
\hline $20-30$ & 42 & 70.0 & 48 & 80.0 & \\
\hline$>30$ & 18 & 30.0 & 9 & 15.0 & \\
\hline Mean \pm SD & $29.5 \pm 4.0$ & $28.1 \pm 4.4$ & $0.09^{\text {ns }}$ \\
\hline
\end{tabular}

$\mathrm{Ns}=$ not significant, $\mathrm{p}$ value reached from Unpaired t-test

Table-II: Serum ferritin concentration in study patients $(n=120)$

\begin{tabular}{|l|l|l|l|}
\hline Duration of gestation (week) & Group A (n=60) & Group B (n=60) & P-Value \\
\cline { 2 - 3 } & Mean \pm SD & Mean \pm SD & \\
\hline Serum Ferritin levels $(\mathrm{ng} / \mathrm{ml})$ & $121.1 \pm 17.7$ & $86.4 \pm 19.9$ & $0.001^{\mathrm{s}}$ \\
\hline
\end{tabular}

$\mathrm{s}=$ significant, $\mathrm{p}$ value reached from Unpaired t-test 


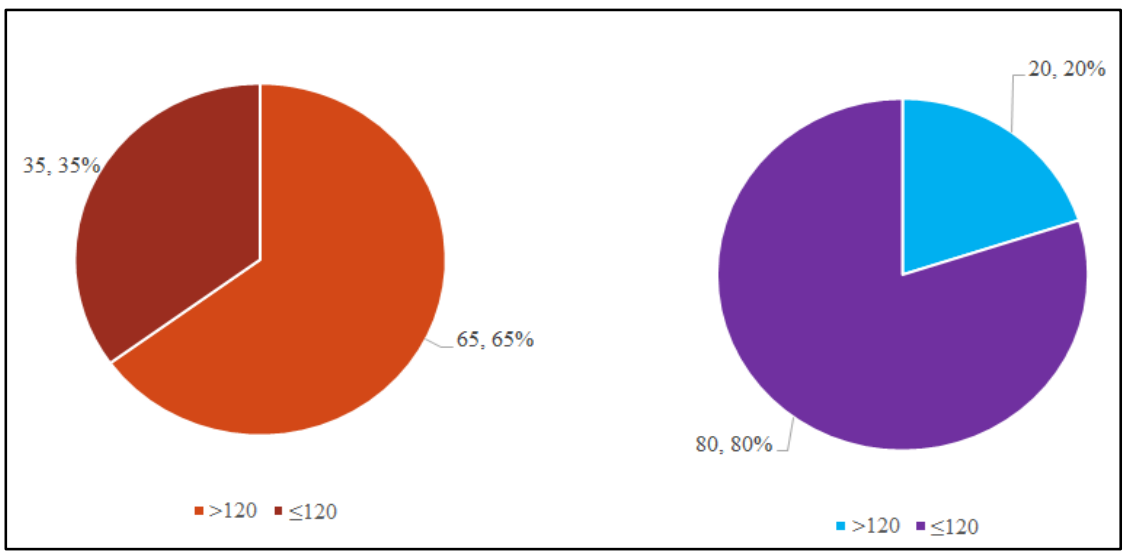

Fig-I: Association between elevated serum ferritin and GDM $(n=120)$

\begin{tabular}{|l|l|}
\hline Serum Ferritin levels $(\mathrm{ng} / \mathrm{ml})$ of Group A $(\mathrm{n}=60)$ & Serum Ferritin levels $(\mathrm{ng} / \mathrm{ml})$ of Group B $(\mathrm{n}=60)$ \\
\hline $\mathrm{OR}(95 \% \mathrm{CI})=3.1(1.6-7.60), \mathrm{p}$ value $=0.001^{\mathrm{s}}(\mathrm{P}$ value performed by Chi-square test, $\mathrm{s}=$ significant $)$ \\
\hline
\end{tabular}

\section{DISCUSSION}

The aim of present study was to; compare serum ferritin level between two groups and to evaluate any association between serum ferritin level and GDM. In this present study, it was observed that $70.0 \%$ patients belonged to age 20-30 years in Group A and $80.0 \%$ in Group B. The mean age was $29.5 \pm 4$ years in Group A and 28.1 \pm 4.4 years in Group B. The difference was statistically not significant $(\mathrm{p}>0.05)$. In this current study $70.0 \%$ patients had multipara in Group A and $39(65.0 \%)$ in Group B. And the mean duration of gestation was 29.3 \pm 3.6 weeks in Group A and 27.6 \pm 3.5 weeks in Group B, which were almost similar between two groups. A significant correlation between higher serum ferritin levels and insulin resistance syndrome has been showed [11-13]. Some studies revealed a significant association between higher serum ferritin and risk of type 2 diabetes [14].

Present study also confirmed that the mean serum ferritin levels were $121.1 \pm 17.7 \mathrm{ng} / \mathrm{ml}$ in Group A and $86.4 \pm 19.9 \mathrm{ng} / \mathrm{ml}$ in Group B, which is significantly $(\mathrm{p}<0.05)$ elevated in Group A. In one study showed that in pregnant women with gestational diabetes, the serum ferritin level was found to be higher $(41 \pm 35$ in GDM and $35.5 \pm 30.7$ in non GDM) in comparison with healthy pregnant women and the difference was statistically significant $(\mathrm{p}<0.05)$ [9]. The risk of type 2 diabetes is increased when the level of ferritin is elevated [15]. Serum ferritin levels were significantly elevated in GDM with compared to non GDM group also observed by many investigators $[14,16,17]$.

The result found in the present study, that $65.0 \%$ patients had serum ferritin level $>120 \mathrm{ng} / \mathrm{ml}$ in Group A and $20.0 \%$ in Group B. Serum ferritin level $>120 \mathrm{ng} / \mathrm{ml}$ had 3.1 (95.0\% C.I. 1.6 to 7.60$)$ times significantly $(\mathrm{p}<0.05)$ increase to developed gestational diabetes mellitus with compared to healthy pregnant women. In a study showed that the risk of having GDM with these high level of ferritin to be 1.4-fold higher than that in subjects with lower ferritin concentrations having OR 1.4 with 95\% CI= 1-1.87 $(\mathrm{p}<0.05)$ [9]. The investigators also reported that after adjusted for age Odds Ratio was 1.38 (95\% CI=1.02-1.86) ( $\mathrm{p}<0.05)$. That high ferritin levels increased the risk of gestational diabetes to 2.4-fold with 95\% $\mathrm{CI}=0.83-6.9(\mathrm{p}<0.05)$ [18]. The risk of having GDM to be more than two fold higher than the risk for those with lower concentrations of ferritin were also observed [19]. The above findings are closely resembled with the present study.

Serum ferritin is significantly higher in GDM when compare with non GDM women. Thus high serum ferritin may be considered as a risk factor for the development of GDM.

\section{REFERENCE}

1. WHO. Guideline: daily iron and folic acid supplementation in pregnant women. Geneva: World Health Organization; 2012.

2. DeCherney AH, Nathan L. Current diagnosis \& treatment obstetrics \& gynecology. Univerza v Ljubljani, Medicinskafakulteta; 2013.

3. Jesmin S, Akter S, Akashi H, Al-Mamun A, Rahman MA, Islam MM, Sohael F, Okazaki O, Moroi M, Kawano S, Mizutani T. Screening for gestational diabetes mellitus and its prevalence in Bangladesh. Diabetes research and clinical practice. 2014 Jan 1;103(1):57-62.

4. Harlev A, Wiznitzer A. New insights on glucose pathophysiology in gestational diabetes and insulin resistance. Current diabetes reports. 2010 Jun;10(3):242-7.

5. Harrison PM, Arosio P. The ferritins: molecular properties, iron storage function and cellular regulation. BiochimBiophysActa. 1996;1275(3):161-203.

6. Torti FM, Torti SV. Regulation of ferritin genes and protein. Blood. 2002;99(10):3505-3516. 
Mahmood S et al; Sch J App Med Sci, Feb, 2021; 9(2): 179-182

7. Lim MK, Lee CK, Ju YS. Serum ferritin as a serologic marker of activity in systemic lupus erythematosus. Rheumatol Int. 2001;20(3):89-93.

8. Gillum RF. Association of serum ferritin and indices of body fat distribution and obesity in Mexican American men--the Third National Health and Nutrition Examination Survey. Int $\mathbf{J}$ Obes RelatMetab Disord. 2001;25(5):639-645.

9. Soheilykhah S, Mojibian M, JannatiMoghadam M. Serum ferritin concentration in early pregnancy and risk of subsequent development of gestational diabetes: A prospective study. Int J Reprod Biomed. 2017;15(3):155-160

10. Wolf M, Sandler L, Hsu K, Vossen-Smirnakis K, Ecker JL, Thadhani R. First-trimester C-reactive protein and subsequent gestational diabetes. Diabetes Care. 2003;26(3):819-824

11. Fernández-Real JM, López-Bermejo A, Ricart W. Cross-talk between iron metabolism and diabetes. Diabetes. 2002;51(8):2348-2354.

12. Kalantar-Zadeh K, Rodriguez RA, Humphreys MH. Association between serum ferritin and measures of inflammation, nutrition and iron in haemodialysis patients. Nephrol Dial Transplant. 2004;19(1):141-149.

13. Mainous AG 3rd, Wells BJ, Everett CJ, Gill JM, King DE. Association of ferritin and lipids with Creactive protein. Am J Cardiol. 2004;93(5):559562.

14. Sharifi F, Ziaee A, Feizi A, Mousavinasab N, Anjomshoaa A, Mokhtari P. Serum ferritin concentration in gestational diabetes mellitus and risk of subsequent development of early postpartum diabetes mellitus. Diabetes MetabSyndrObes. 2010;3:413-419.

15. Jiang R, Manson JE, Meigs JB, Ma J, Rifai N, Hu FB. Body iron stores in relation to risk of type 2 diabetes in apparently healthy women. JAMA. 2004;291(6):711-717.

16. Chen X, Scholl TO, Stein TP. Association of elevated serum ferritin levels and the risk of gestational diabetes mellitus in pregnant women: The Camden study. Diabetes Care. 2006;29(5):1077-1082.

17. Islam N, Chowdhury S, Kazal R, Rahman R, Parveen H, Begum K and Chowdhury SB.Serum ferritin and gestational diabetes mellitus: A case control study. Journal of Bangladesh College of Physicians \& Surgeons. 2012; 30, 205-210.

18. Amiri FN, Basirat Z, Omidvar S, Sharbatdaran M, Tilaki KH, Pouramir M. Comparison of the serum iron, ferritin levels and total iron-binding capacity between pregnant women with and without gestational diabetes. J Nat SciBiol Med. 2013; 4(2):302-305.

19. Soubasi V, Petridou S, Sarafidis K. Association of increased maternal ferritin levels with gestational diabetes and intra-uterine growth retardation. Diabetes Metab. 2010;36(1):58-63. 